
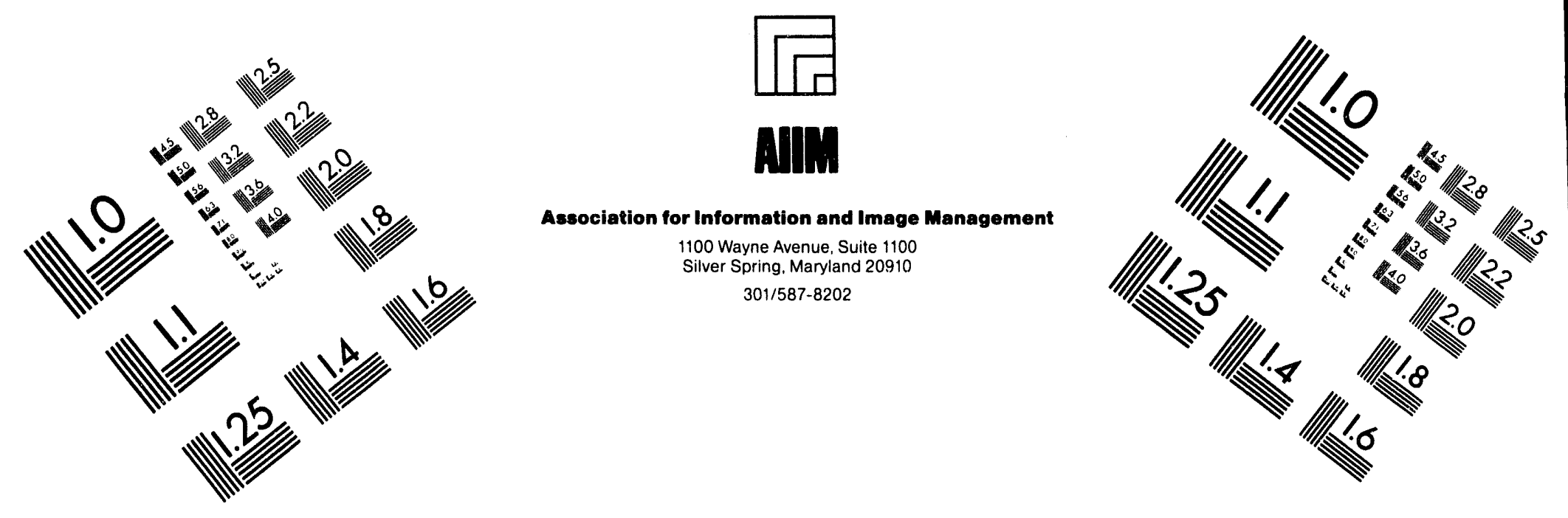

Centimeter

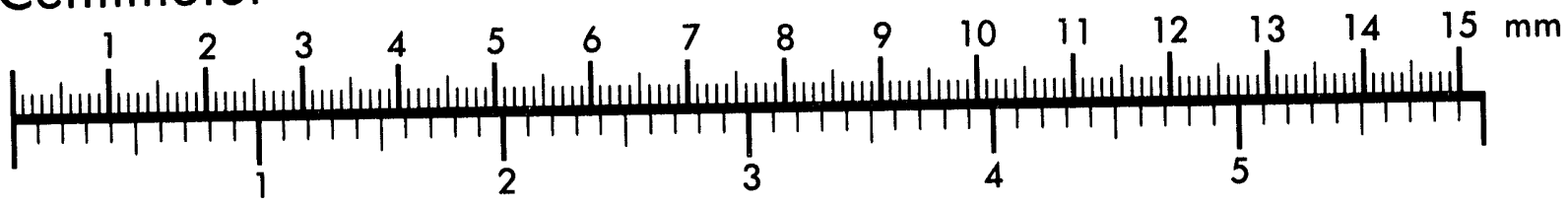
Inches
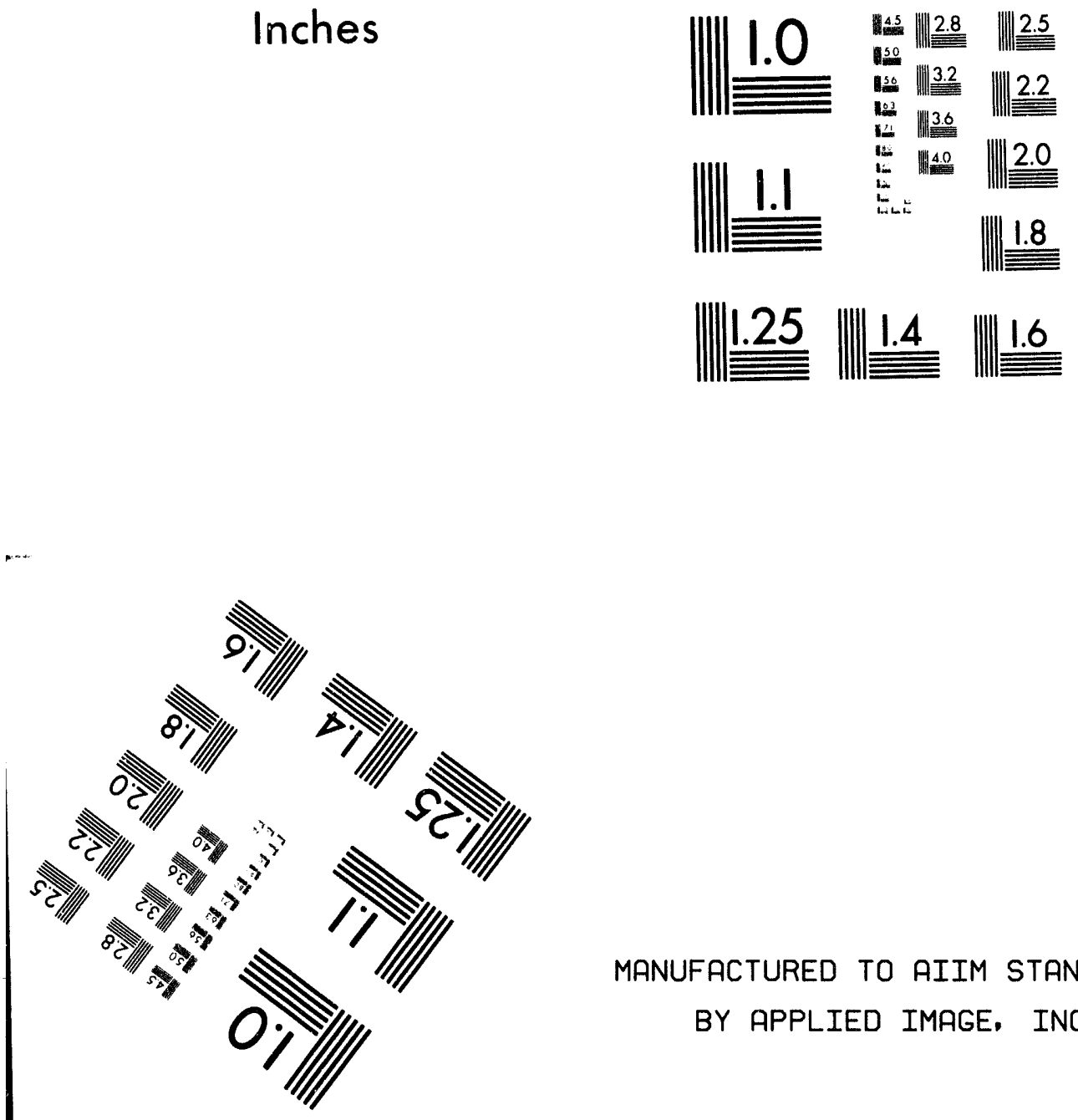

MANUFACTURED TO AIIM STANDARDS BY APPLIED IMAGE, INC.

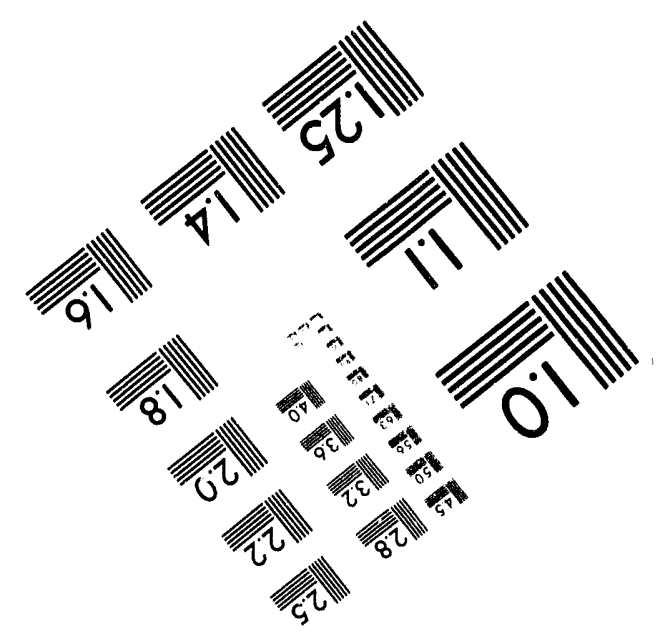



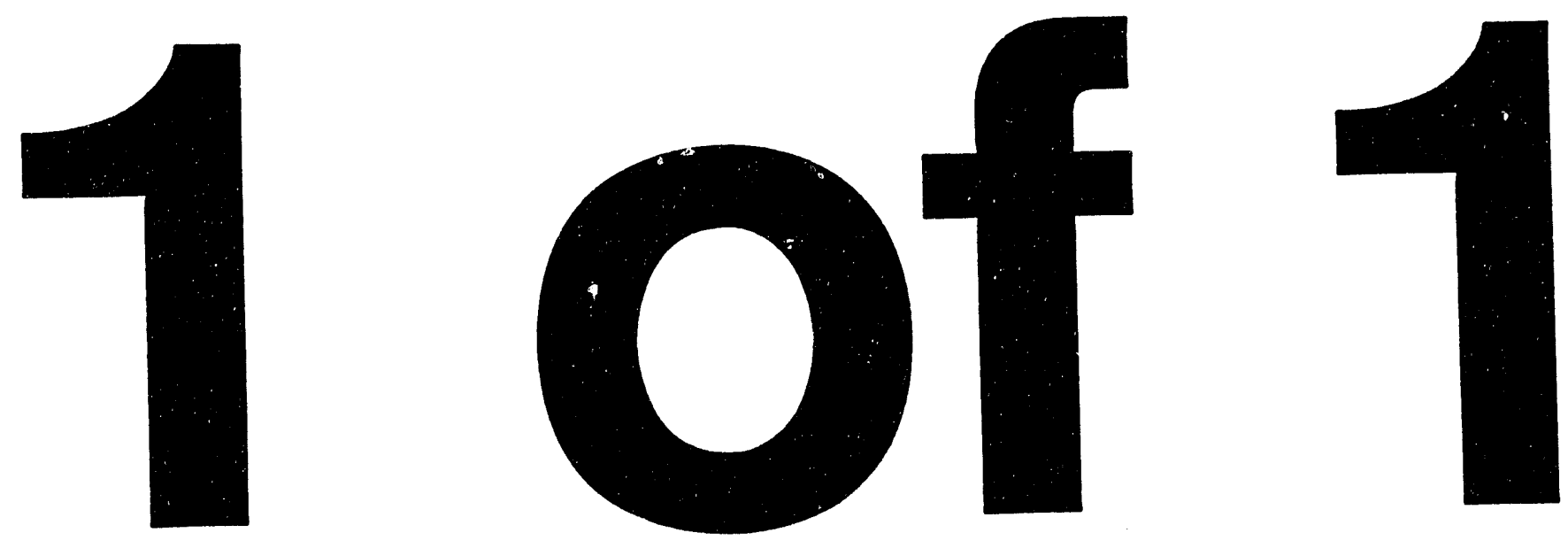


\section{Tensile Properties of Irradiated Surveillance Coupons}

Prepared for the U.S. Department of Energy Office of Environmental Restoration and Waste Management

\section{(W) Westinghouse Hanford Company Richland, Washington}

Hanford Operations and Engineering Contractor for the

U.S. Department of Energy under Contract DE-AC06-87RL 10930

Copyright License By a:reptance ol this article, the publisher and/or recipient acknowledges the U S. Government's right to retain a nonexolusive, loyally-itos license in and to any copyright covering this paper 
LEGAL DISCLAIMER

This report was prepared as an account of work sponsored by an agency of the United States Government. Neither the

United States Government nor any agency thereol, nor any of their employees, nor any of their conlractors, subcontractors or their employees, makes any warranty, express or implied or assumes any legal liability or responsibility for the accuracy, completeness, or any third party's use or the results of such use of any information, apparatus, product, or process disclosed, or represents that its use would not infringe privately owned rights. Reference herein to any specille commercial producl, process, or service by trade name, trademark, manulacturer, or otherwise, does not necessarily constitute or imply its endorsement, recommendation, or lavoring by the United Slates Government or any agency thereof or its contractors or subcontractors. The views and opinions of authors expressed herein do not necessarily state or reflect those of the United States Government or any agency thereot.

This report has been reproduced from the best available cupy.

Prinled in the United States of America

$\operatorname{OISCLM-2.CHP(1.91)}$ 


\title{
Tensile Properties of Irradiated Surveillance Coupons
}

\author{
F. H. Huang \\ L. D. Blackburn
}

Date Published

June 1994

Prepared for the U.S. Department of Energy Office of Environmental Restoration and Waste Management

\section{(2) Westinghouse \\ P.O. Box 1970 \\ Hanford Company Richland, Washington 99352}

Hanford Operations and Engineering Contractor for the U.S. Department of Energy under Contract DE-AC06-87RL10930

Copyright Llcense By acceptance of this article, the publisher and/or recipient acknowledges the U.S Government's right to retain a nonexclusive, royahty.free license in and to any copyright covering this paper 


\title{
TENSILE PROPERTIES OF IRRADIATED SURVEILLANCE COUPONS
}

\author{
F. H. Huang
}

L. D. Blackburn

\begin{abstract}
Tensile testing of austenitic steel and superalloy samples irradiated in the HMO 13 assembly was performed in support of the Fast Flux Test Facility (FFTF) Surveillance Program. Postirradiation yield stress, ultimate tensile stress, uniform elongation, total elongation, and reduction in area of 304 stainless stee1 (SS), 308 SS weld, 316 SS, A286, In718, and In718 weld were determined. Results showed the strength of austenitic steels increased while the ductility decreased as a result of irradiation. Low irradiation exposure produced 1ittle property change in In718. Overal1, the tensile properties of HMO 13 surveillance coupons showed a lower magnitude of irradiation-induced property change than was expected based on earlier studies. Results from these tests gave no indications of unexpectedly severe irradiation damage to FFTF components.
\end{abstract}

\subsection{INTRODUCTION}

Surveillance coupons fabricated from the actual heats of materials used for reactor components have been retrieved from irradiation assembly HMO 13. These coupons were located at assembly positions where neutron fluxes were higher than that of the actual reactor component they represent. Swelling measurements on selected coupons have been reported. This report presents results of mechanical property tests.

Tensile tests were conducted on sixteen HM013 surveillance coupons fabricated from 304 stainless steel (SS), 308 SS, 316 SS, Inconel 718 and alloy A286. Alloy 718 is a high-strength, precipitation hardenable nickelbase superalloy. Testing of these surveillance coupons identifies the extent of radiation-induced degradation in material property for comparison with the results of earlier studies that guided considerations of irradiation effects for FFTF design.

\subsection{EXPERIMENTAL}

\subsection{SPECIMEN PREPARATION}

Three types of specimens were irradiated in the HMO 13 assembly but only Fermi tensile specimens were tested in this work. The Fermi specimen and the grips used in the hotcell are shown in Figure 1. The specimen is $47.63 \mathrm{~mm}$ long with a gauge section diameter of $3.18 \mathrm{~mm}$. 
Irradiation temperature was measured in a 1 imited number of subcapsules containing thermal expansion difference (TED) monitors, the temperatures in all subcapsules were estimated by comparing the temperature measured by TED monitors and design temperatures. The temperature profiles for all subcapsules in sample rods $A$ and $B$ are shown in Figure 3 . Based on this temperature profile, the irradiation temperature in the subcapsule containing no TED was estimated. Both design and measured temperatures for the subcapsules containing the Fermi tensile specimens tested in this work are listed in Table 1.

The damage levels in the subcapsules containing the dosimeters were analyzed based on the counting results obtained from the dosimetry packets. The results of dosimetry analys is are given in Reference 1 . Table 1 lists the neutron fluence for each sample.

\subsection{TEST PROCEDURE}

Tensile tests were conducted in the hotcell using a screw-driven testing machine. All measurement and test equipment, such as voltmeters, recorders and thermocouples, were calibrated.

The basic procedures for this tensile testing are as follows:

1. All specimens were tested at $471^{\circ} \mathrm{C}$ using a screw-driven machine operated at a crosshead speed of $0.05 \mathrm{~mm} / \mathrm{min}$ and an initial load scale of $907 \mathrm{~kg}$.

2. After the test was completed, each broken specimen was reassembled to measure the final length.

3. Yield and ultimate tensile strength, uniforms and total elongation were determined from load-displacement records.

4. The reduction in area was computed from the final cross section of the sample.

\subsection{RESULTS}

Unirradiated specimens, fabricated from the same heats of materials as the FFTF surveillance coupons, were tested much earlier. The preirradiation tensile properties of HMO 13 control specimens, along with the heat number and test temperature, are compiled in Table 2. The test parameters as well as the 0.2 percent offset yield strength (YS), ultimate tensile strength (UTS), reduction in area, uniform (UE) and total elongation (TE) are summarized in Table 3 .

An extensive data base of the effect of irradiation in the Experimental Breeder Reactor II on the tensile properties of 304 SS, 316 SS, and 308 SS weld metal has been analyzed. These earlier studies showed that both irradiation temperature and irradiation exposure can be important in determining the extent of change in a mechanical property. In some cases, differences in the magnitude of irradiation-induced property change were 
detected between different heats of steel. Results on the change in strength properties for austenitic stainless steels irradiated in HMO13 are plotted against neutron exposure in Figures 3 and 4 . The yield strength of 304 SS (Figure 3) increases with neutron exposure at low displacement damage levels, but reaches a $1 \mathrm{imiting}$ value of about $286 \mathrm{MPa}$ for exposures of about $8 \mathrm{dpa}$ and higher. Ultimate strength shows some variability, but no consistent change with neutron exposure. This type of response is typical of that observed in prior experiments, but the magnitude of the strength increase is smaller than expected on the basis of the earlier studies cited above. Yield and ultimate strengths for 308 SS (Figure 4) irradiated at about $447^{\circ} \mathrm{C}$ to exposures below 3 dpa appear to show a small decrease relative to those properties for unirradiated material. The specimen irradiated to $8.5 \mathrm{dpa}$ (displacement per atom) show significantly higher strength because the irradiation temperature was lower $\left(397^{\circ} \mathrm{C}\right)$. Once again, comparison with the earlier investigations indicates higher strength values should be expected at the lower irradiation temperature.

Results for uniform and total elongation are plotted in Figures 5 and 6 . In the case of 304 SS (Figure 5), the decrease in elongation at low neutron exposures is consistent with the increase in yield strength in this exposure range. The low values of elongation at $5.3 \mathrm{dpa}$ is attributed to data variability rather than to a real data trend. In general, elongation values are somewhat higher than those observed in earlier investigations. The 308 SS weld (Figure 6 ) exhibits a modest reduction in elongation at low exposures (irradiation temperature about $477^{\circ} \mathrm{C}$ ), although the values seem somewhat lower, relative to the unirradiated condition, than would be expected from the yield strength changes. The low elongations at $8.5 \mathrm{dpa}$ for an irradiation temperature of $397^{\circ} \mathrm{C}$ are consistent with results from the earlier studies.

Results for Inconel 718 and alloy A286 at low neutron exposures generally indicate small increases in strength and small decreases in ductility relative to properties of unirradiated material. The combination of neutron irradiation and elevated temperature during the in-reactor exposure clearly produced a materfal with high strength. The relative contributions of neutron displacement damage or irradiation-enhanced precipitation hardening to the observed effect cannot be assessed. Small changes in strength and ductility for precipitation strengthened Inconel 718 are generally consistent with earlier work for an irradiation temperature of about $377^{\circ} \mathrm{C}$.

\subsection{DISCUSSION}

There is no readily acceptable explanation for the low magnitude of irradiation strengthening and generally higher ductility observed in stainless steels from HM013 relative to that expected from earlier studies. The only hypothesis that can be advanced at this time is that irradiation temperatures may actually have been significantly higher than the analys is of TED monitors indicated. 


\subsection{CONCLUSION}

Testing of coupons from the HMO13 survelliance assembly showed that the irradiation exposure generally increased strength and reduced elongation for austenitic stainless steels, and had 1ittle effect on strength and elongation of In718 and Alloy A286. In genera1, HMO 13 coupons of austenitic stainless steels exhibited lower values of strength increase and ductility decrease than expected based on results from earlier EBR-II irradiations. Results from these tests give no indications of unexpectedly severe irradiation damage to FFTF components.

\subsection{REFERENCES}

1. R. L. Simons and R. H. Webb, "FFTF Surveillance Irradiation Assembly, HMO 13 Dosimetry Analys is," WHC-SA-1311-FP, Wstinghouse Hanford Company, Richland, Washington, 1991. 


\begin{tabular}{|c|c|c|c|c|c|c|c|}
\hline $\begin{array}{c}\text { Specimen } \\
\text { I.D. }\end{array}$ & Material & Heat Number & Subcapsule & $\begin{array}{c}\text { Design } \\
\text { Temp. } \\
\left({ }^{\circ} \mathrm{F}\right)\end{array}$ & $\begin{array}{l}\text { Measured } \\
\text { Temp. } \\
\left({ }^{\circ} \mathrm{F}\right)\end{array}$ & $\begin{array}{c}\text { Damage } \\
\text { (dpa) }\end{array}$ & Component \\
\hline N33 & 304 SS & $\times 23171$ & $12 A 8$ & 890 & 919 & 17.0 & RS-5 \\
\hline M32 & & $626577-1$ & $12 \mathrm{~B} 7$ & 870 & 961 & 15.0 & RS -13 \\
\hline F94 & & $8394-1 A$ & $12 A 10$ & 850 & 880 & 5.3 & CR-6 \\
\hline P56 & & $326284-2 B$ & $12 \mathrm{~A} 11$ & 855 & 885 & 2.9 & RS-4 \\
\hline $\mathrm{J5}$ & & 633377 & $12 A 17$ & 860 & 890 & 0.1 & IV -3 \\
\hline M37 & 308 SS & $326284-1 B /-2 B$ & $12 \mathrm{~A} 11$ & 855 & 885 & 2.9 & RS-6 \\
\hline M35 & & SAME & $12 \mathrm{~A} 12$ & 860 & 890 & 1.7 & RS-6 \\
\hline$\llcorner 62$ & & $326284-2 /-1 A$ & $12 \mathrm{~A} 14$ & 860 & 890 & 0.6 & RS-7 \\
\hline$\lfloor 51$ & & SAME & $12 \mathrm{~B} 2$ & 700 & 746 & 8.5 & RS-7 \\
\hline H60 & IN718 & C52227 & $12 A 9$ & 870 & 900 & 8.6 & CR-8 \\
\hline H75 & & $8-4014$ & $12 \mathrm{~B} 16$ & 815 & 882 & 0.062 & IV -2 \\
\hline L39 & & C52325 & $12 A 16$ & 860 & 890 & 0.2 & $C D-1$ \\
\hline $\mathrm{L} 74$ & IN718 Weld & C523525 & $12 \mathrm{~A} 16$ & 860 & 890 & 0.2 & $C D-3$ \\
\hline H67 & A286 & 62570R11 & $12 \mathrm{~A} 17$ & 860 & 890 & 0.1 & IV-I \\
\hline E29 & 316 SS & 66236 & $12 \mathrm{AB}$ & 890 & 919 & 17.0 & $R R-2 b$ \\
\hline H29 & 304 SS & 36832 & $12 A 9$ & 870 & 900 & 8.6 & CR-7 \\
\hline
\end{tabular}

NOTE: All tests were conducted at a crosshead speed of $0.002 \mathrm{in} / \mathrm{min}$ 


\begin{tabular}{|c|c|c|c|c|c|c|c|}
\hline \multirow{2}{*}{ Material } & \multirow{2}{*}{ Heat Number } & \multirow{2}{*}{$\begin{array}{l}\text { Test } \\
\text { Temp } \\
\left({ }^{\circ} \mathrm{C}\right)\end{array}$} & \multicolumn{2}{|c|}{ Strength (Mpa) } & \multicolumn{2}{|c|}{ Elongation (\%) } & \multirow[b]{2}{*}{ Component } \\
\hline & & & Yield & U7timate & Uniform & Total & \\
\hline 304 SS & $\begin{array}{l}X 23171 \\
626577-1 \\
8394-1 A \\
326284-2 B \\
633377 \\
36832 \\
\end{array}$ & $\begin{array}{l}475 \\
440 \\
455 \\
425 \\
504 \\
465 \\
\end{array}$ & $\begin{array}{l}138.8 \\
177.9 \\
136.1 \\
135.7 \\
158.2 \\
137.3 \\
\end{array}$ & $\begin{array}{l}434.4 \\
462.6 \\
446.4 \\
440.1 \\
407.6 \\
420.9 \\
\end{array}$ & $\begin{array}{l}37.4 \\
34.5 \\
34.0 \\
34.2 \\
30.7 \\
32.2 \\
\end{array}$ & $\begin{array}{l}41.8 \\
40.5 \\
39.7 \\
40.7 \\
36.4 \\
38.2 \\
\end{array}$ & $\begin{array}{l}\text { RS-5 } \\
\text { RS-13 } \\
\text { CR-6 } \\
\text { RS-4 } \\
\text { IV-3 } \\
\text { CR-72 } \\
\end{array}$ \\
\hline 308 SS & $\begin{array}{l}326284-1 B / 2 B \\
326284-2 / 1 A\end{array}$ & $\begin{array}{l}455 \\
370 \\
\end{array}$ & $\begin{array}{l}354.6 \\
410.2 \\
\end{array}$ & $\begin{array}{l}475.8 \\
489.2 \\
\end{array}$ & $\begin{array}{l}17.1 \\
16.0 \\
\end{array}$ & $\begin{array}{l}20.6 \\
19.3 \\
\end{array}$ & $\begin{array}{l}\text { RS-6 } \\
\text { RS-7 } \\
\end{array}$ \\
\hline IN718 & $\begin{array}{l}C 52227 \\
8-4014 \\
C 52325 \\
\end{array}$ & $\begin{array}{l}465 \\
504 \\
420 \\
\end{array}$ & $\begin{array}{l}442.9 \\
981.8 \\
944.3 \\
\end{array}$ & $\begin{array}{r}833.3 \\
1123.4 \\
1102.2 \\
\end{array}$ & $\begin{array}{r}34.8 \\
8.4 \\
12.2 \\
\end{array}$ & $\begin{array}{l}37.4 \\
12.3 \\
17.7 \\
\end{array}$ & $\begin{array}{l}\text { CR-8 } \\
\text { IV-2 } \\
\text { CD-1 } \\
\end{array}$ \\
\hline IN718 Weld & C52325 & 420 & 962.7 & 1120.7 & 9.7 & 11.3 & $C D-3$ \\
\hline A286 & L2570K11 & 504 & 711.5 & 974.7 & 11.7 & 16.4 & IV-1 \\
\hline
\end{tabular}

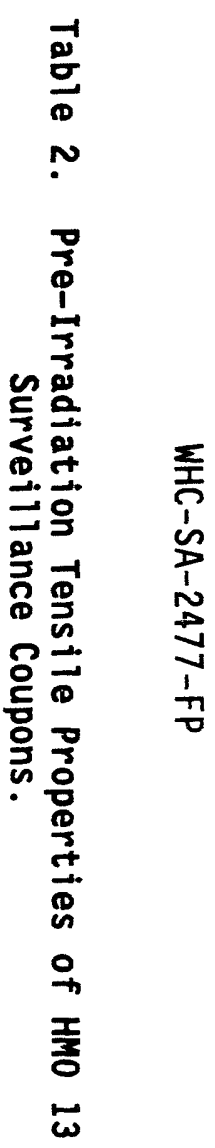




\begin{tabular}{|c|c|c|c|c|c|c|c|c|}
\hline \multirow[b]{2}{*}{$\begin{array}{l}\text { Specimen } \\
\text { I.D. }\end{array}$} & \multirow[b]{2}{*}{ Material } & \multirow[b]{2}{*}{$\begin{array}{l}\text { Damage } \\
\text { (dpa) }\end{array}$} & \multicolumn{2}{|c|}{ Strength (MPa) } & \multirow[b]{2}{*}{$\begin{array}{c}\text { Reduction } \\
\text { in Area } \\
(\%)\end{array}$} & \multicolumn{3}{|c|}{ Elongation (\%) } \\
\hline & & & Yield & Ultimate & & Uniform & $\begin{array}{c}\text { Total } \\
(X-Y \\
\text { Record) }\end{array}$ & $\begin{array}{c}\text { Total } \\
\text { (Direct } \\
\text { Measure) }\end{array}$ \\
\hline N33 & 304 SS & 17.0 & 286.9 & 439.9 & 15.4 & 12.4 & 15.4 & 15.9 \\
\hline M32 & & 15.0 & 277.0 & 433.2 & 18.3 & 15.1 & 17.1 & 16.9 \\
\hline $\mathrm{H} 29$ & & 8.6 & 286.2 & 424.2 & 7.8 & 11.6 & 13.1 & 13.6 \\
\hline F94 & & 5.3 & 262.7 & 375.3 & 10.9 & 7.7 & 11.4 & 10.5 \\
\hline P56 & & 2.9 & 211.3 & 420.8 & 24.0 & 24.2 & 27.0 & 29.8 \\
\hline $\mathrm{J5}$ & & 0.1 & 144.7 & 417.4 & 40.4 & 32.7 & 36.2 & 38.1 \\
\hline E29 & 316 SS & 17.0 & 290.3 & 472.5 & 16.8 & 12.8 & 15.6 & 16.7 \\
\hline$\lcm{L 51}$ & 308 SS & 8.5 & 586.2 & 592.2 & 9.4 & 0.7 & 4.2 & 2.7 \\
\hline M37 & & 2.9 & 304.8 & 414.6 & 22.6 & 10.8 & 14.1 & 14.2 \\
\hline M35 & & 1.7 & 331.1 & 433.2 & 22.6 & 10.7 & 13.6 & 14.7 \\
\hline$L 62$ & & 0.6 & 281.9 & 421.4 & 7.8 & 12.0 & 16.7 & 16.5 \\
\hline $\mathrm{H} 60$ & IN718 & 8.6 & 936.4 & 1123.7 & 19.0 & 12.8 & 13.4 & 13.5 \\
\hline L39 & & 0.2 & 991.1 & 1095.6 & 19.7 & 8.9 & 11.5 & 13.4 \\
\hline $\mathrm{H} 75$ & & 0.062 & 1075.1 & 1193.9 & 19.7 & 7.0 & 9.6 & 9.9 \\
\hline$L 74$ & IN718 Weld & 0.2 & 1016.6 & 1151.8 & 16.8 & 8.3 & 10.6 & 11.6 \\
\hline $\mathrm{H} 67$ & A286 & 0.1 & 796.1 & 1055.1 & 15.4 & 11.8 & 14.6 & 15.4 \\
\hline
\end{tabular}


Figure 1. Fermi Tensile Specimen and Grips.
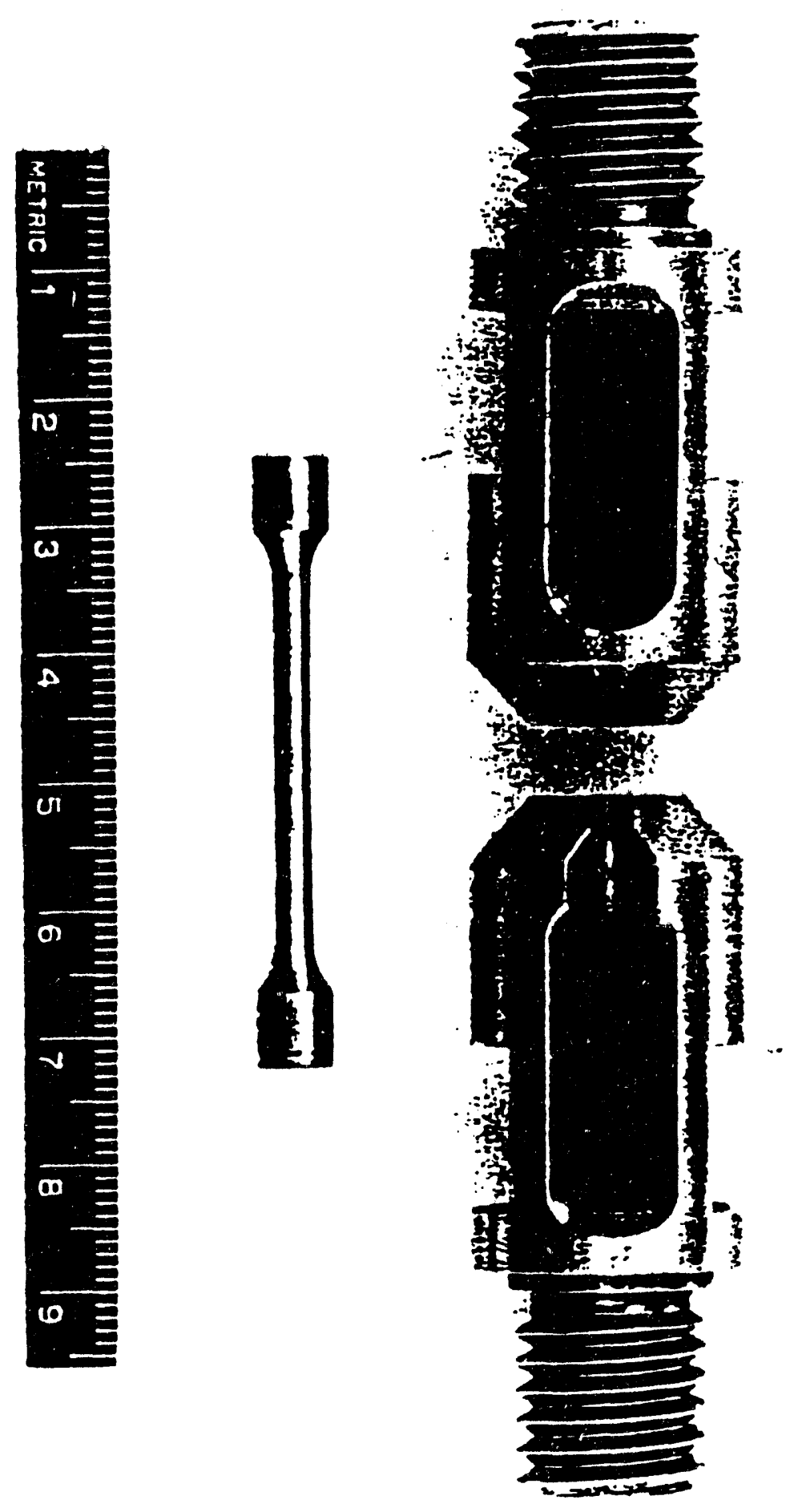
Figure 2. Design Temperature and Irradiation Temperature Measured by TED for Axial Location.

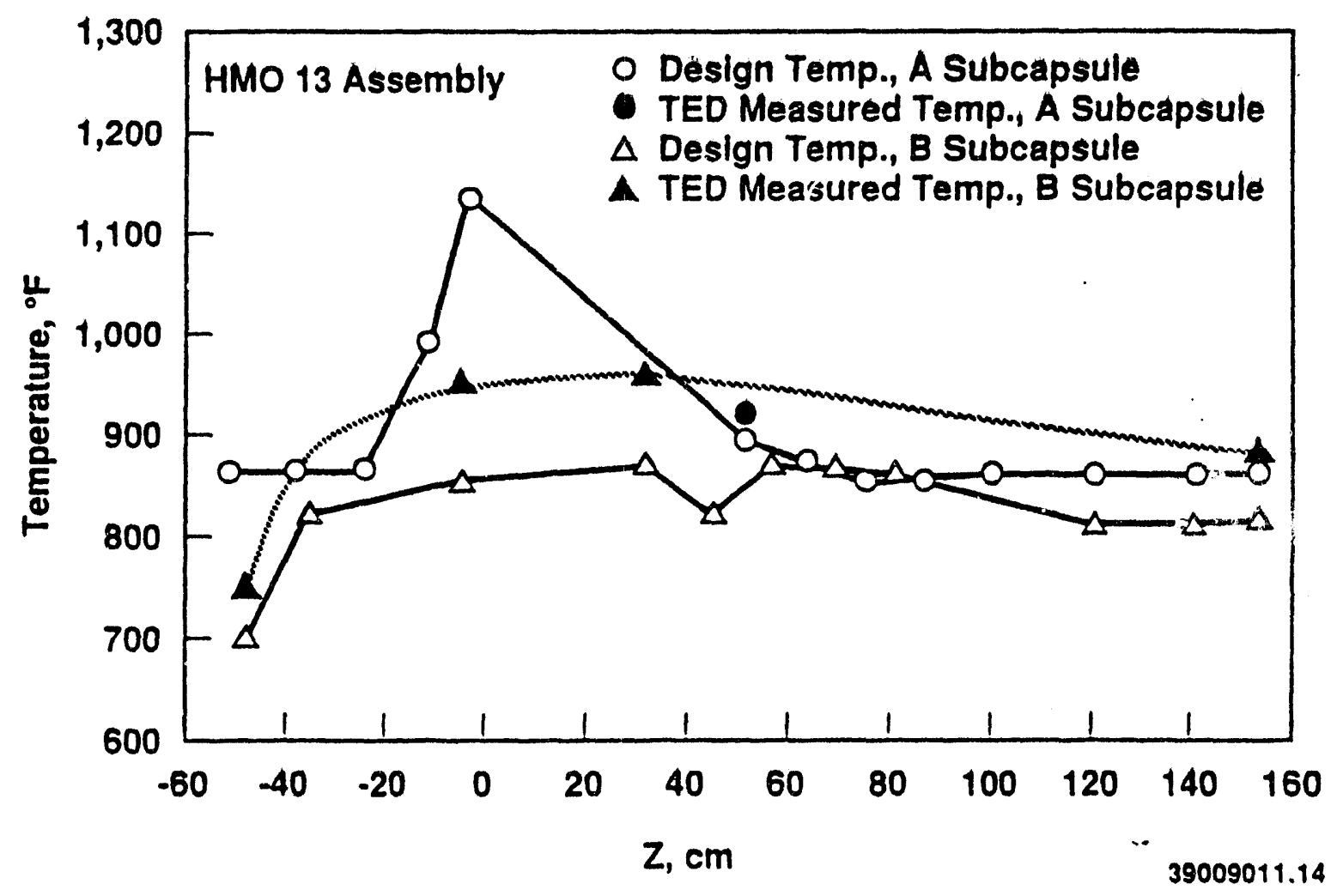


Figure 3. Damage Dependence of Strength for 304 Stainless Stee1 and 316 Stainless Steel.

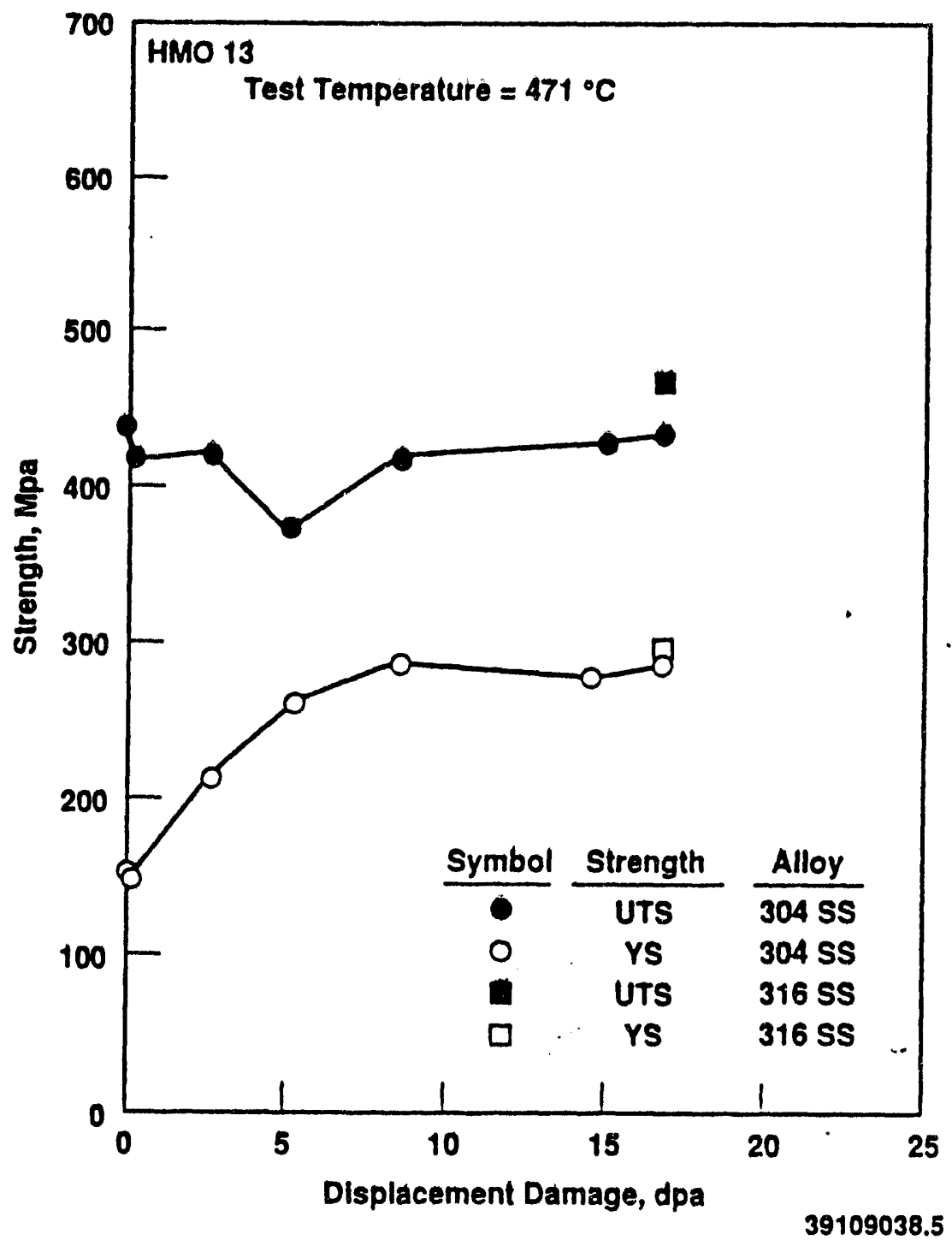


WHC-SA-2477-FP

Figure 4. Damage Dependence of Strength for 308 Stainless Steel Weld.

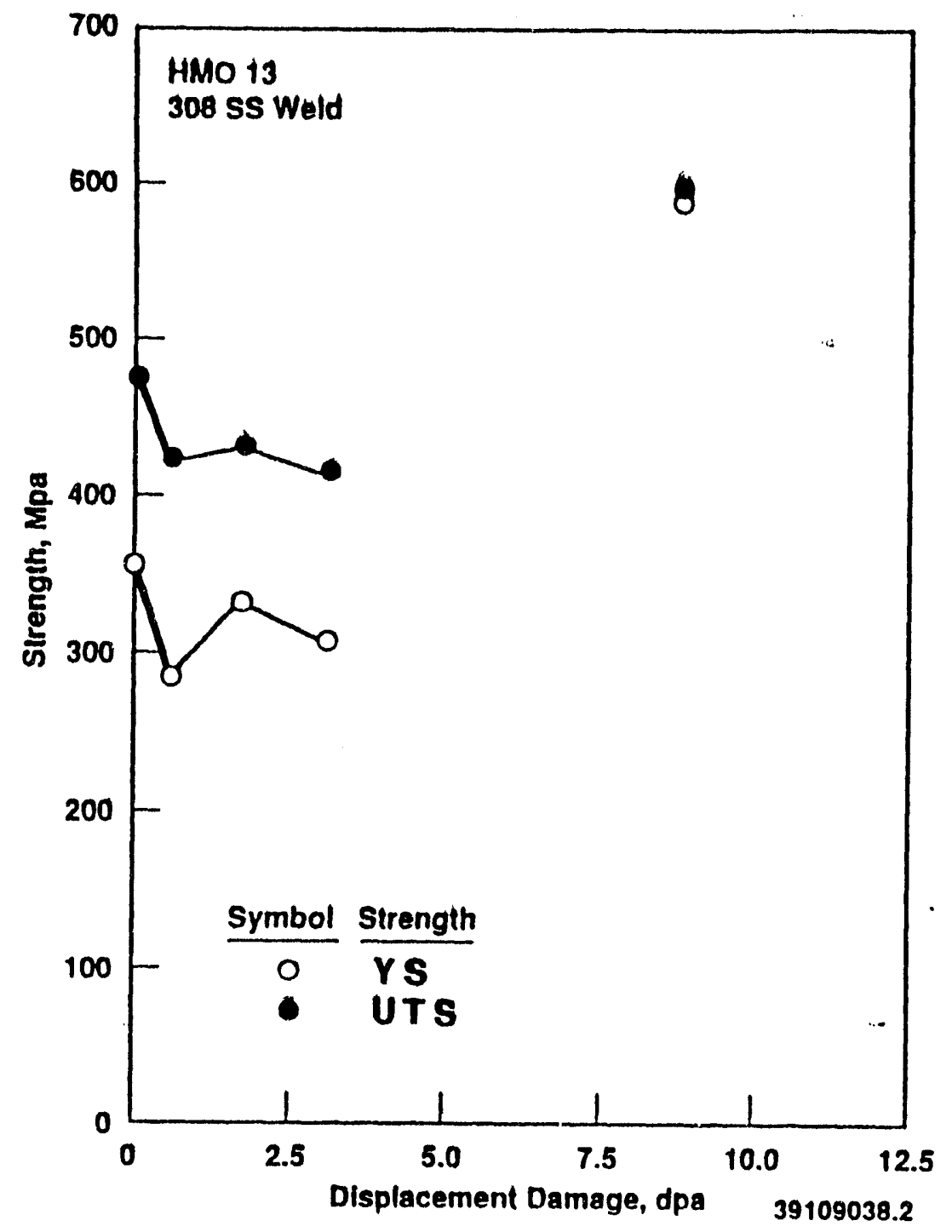


WHC-SA-2477-FP

Figure 5. Damage Dependence of Elongation for 304 Stainless Steel and 316 Stainless Steel.

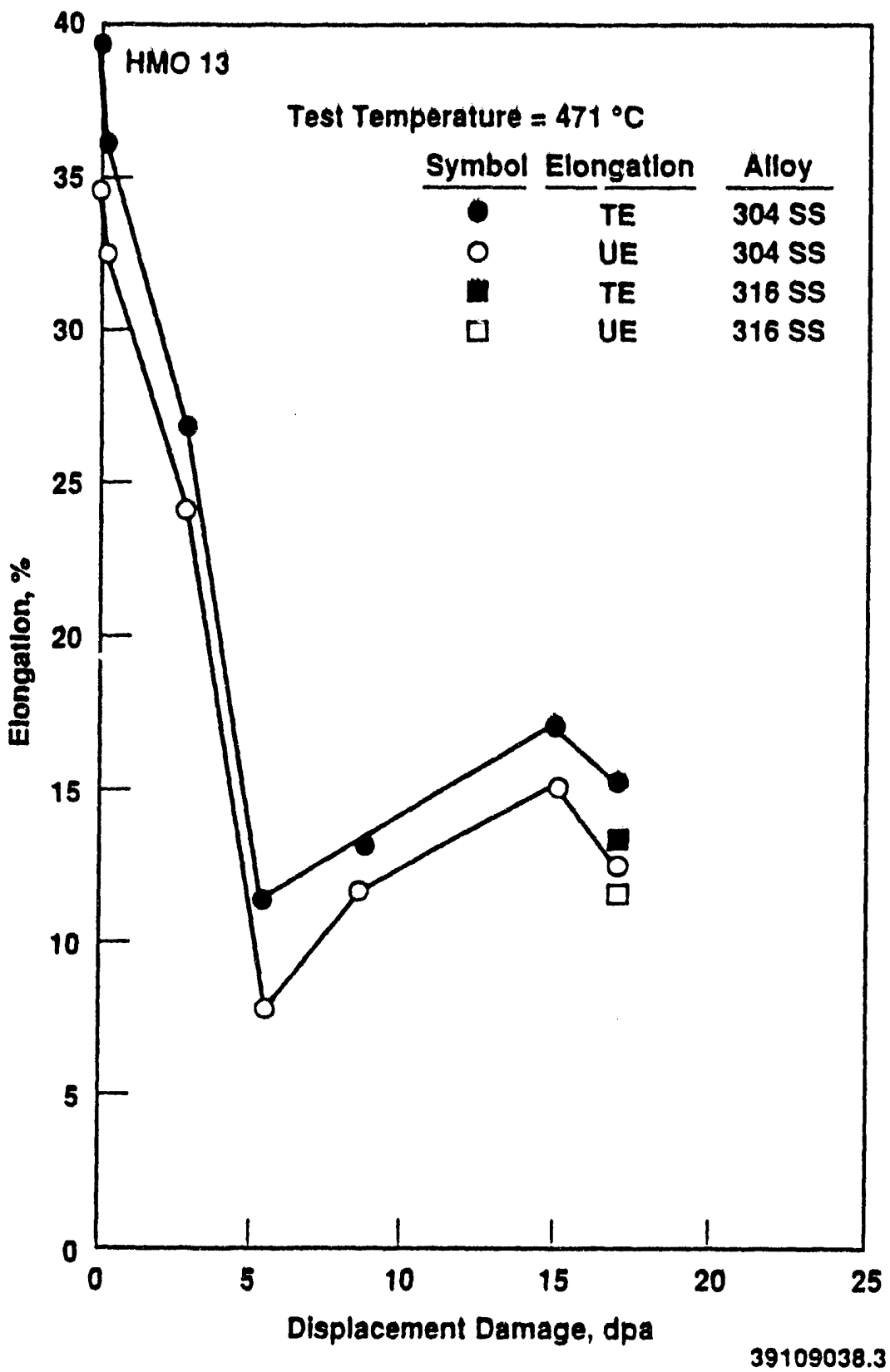


WHC-SA-2477-FP

Figure 6. Damage Dependence of Elongation for 308 Stainless Steel Weld.

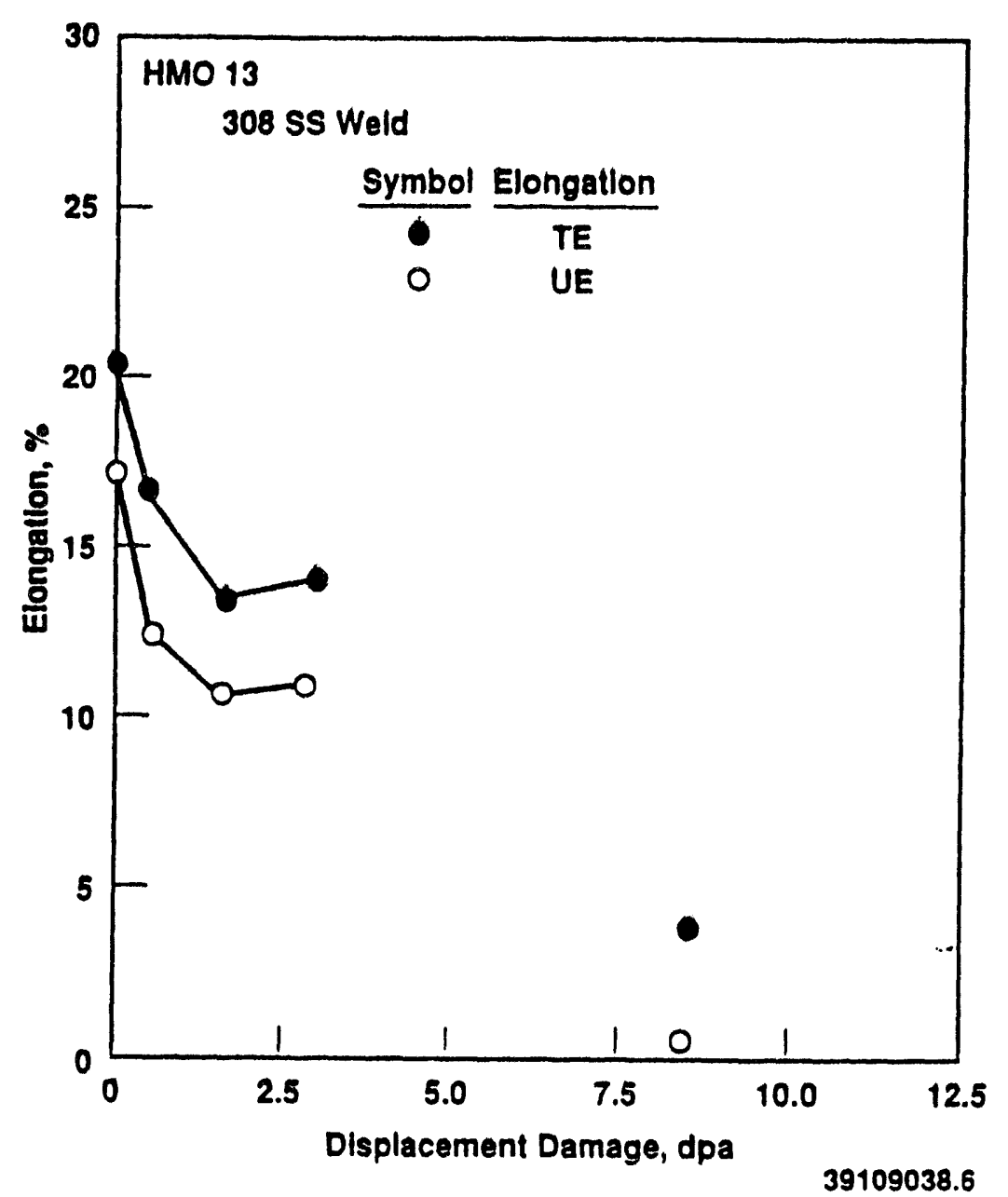



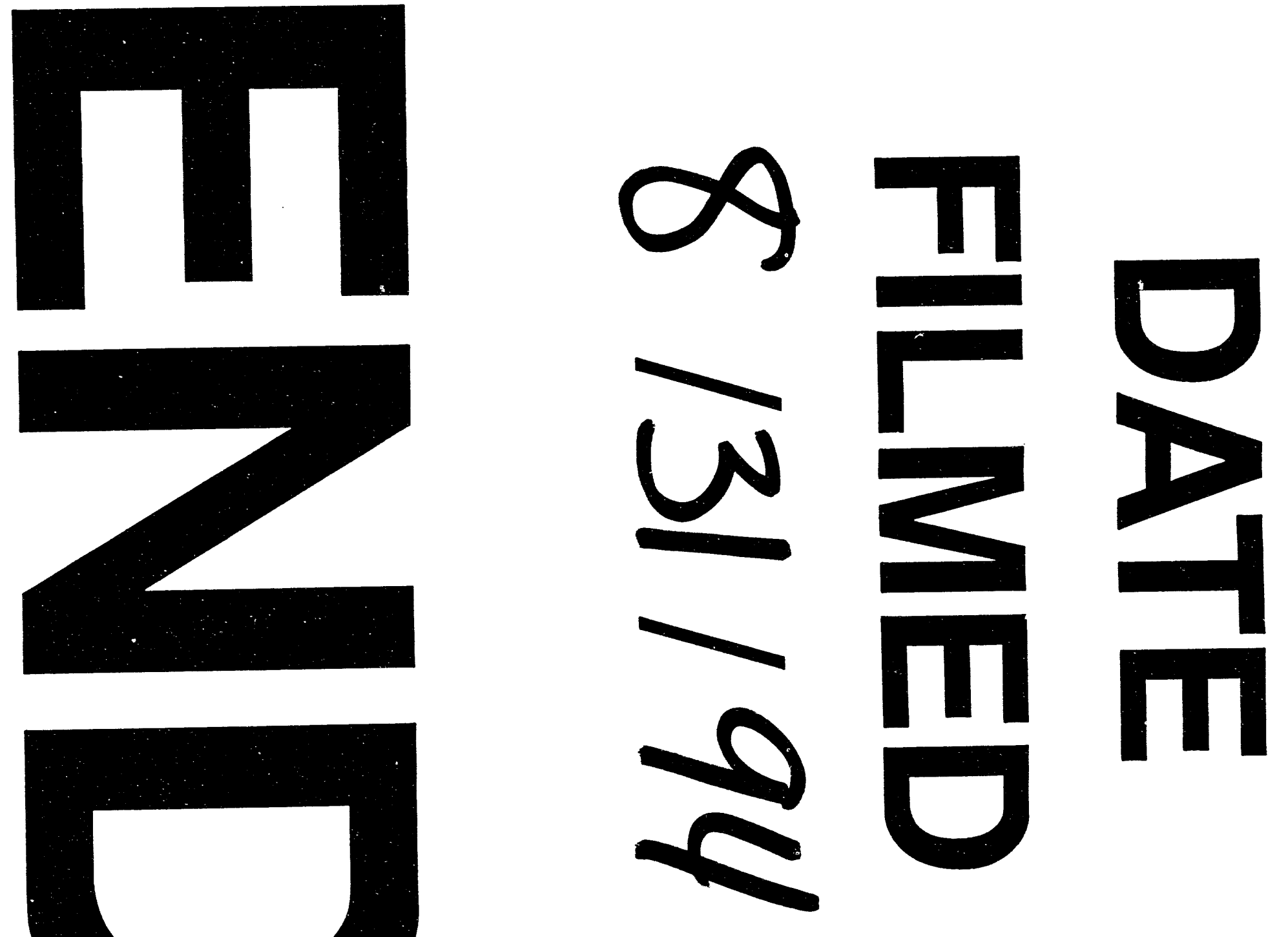
